\title{
DEFINITION AND FUNCTION OF PATENTS
}

\author{
DYAN PURNADIGAMA \\ 155100100 \\ Fakultas Komputer \\ dyanpurnadigama.student@umitra.ac.id
}

\begin{abstract}
A patent is a form of intellectual property. A patent gives its owner the right to exclude others from making, using, selling, and importing an invention for a limited period of time, usually twenty years. The patent rights are granted in exchange for an enabling public disclosure of the invention. People who are employed to do research are often obligated by their employment contracts to assign inventions to their employer. In most countries patent rights fall under civil law and the patent holder needs to sue someone infringing the patent in order to enforce their rights. In some industries patents are an essential form of competitive advantage; in others they are irrelevant. ${ }^{[1]: 17}$

The procedure for granting patents, requirements placed on the patentee, and the extent of the exclusive rights vary widely between countries according to national laws and international agreements. Typically, however, a granted patent application must include one or more claims that define the invention. A patent may include many claims, each of which defines a specific property right. These claims must meet relevant patentability requirements, such as novelty, usefulness, and nonobviousness. ${ }^{[2][3]}$
\end{abstract}

Kata Kunci: Definition And Function 


\section{A. INTRODUCTION}

\section{DEFINITION}

The word patent originates from the Latin patere, which means "to lay open" (i.e., to make available for public inspection). It is a shortened version of the term letters patent, which was an open document or instrument issued by a monarch or government granting exclusive rights to a person, predating the modern patent system. Similar grants included land patents, which were land grants by early state governments in the USA, and printing patents, a precursor of modern copyright.

In modern usage, the term patent usually refers to the right granted to anyone who invents something new, useful and non-obvious. Some other types of intellectual property rights are also called patents in some jurisdictions: industrial design rights are called design patents in the US, ${ }^{[6]}$ plant breeders' rights are sometimes called plant patents, ${ }^{[7]}$ and utility models and Gebrauchsmuster are sometimes called petty patents or innovation patents.

The additional qualification utility patent is sometimes used (primarily in the US) to distinguish the primary meaning from these other types of patents. Particular species of patents for inventions include biological patents, business method patents, chemical patents and software patents.

\section{Patent Rights Function}

The Rights Function is confirmed if according to patent law No.13 of 1997 , patent rights are special rights granted by the State to the inventor of his invention in the field of technology for a certain period of time, carry out the invention himself or give approval to others to give, and there are several that is:

1. Provide legal protection for any intellectual work in the field of technology, so that the patent holder's ownership rights are guaranteed.

2. Realizing a better climate for inventive activities in the field of 
technology, because technology has a very important role in national development in general and especially in the industrial sector,

3. Providing incentives for inventors in making new innovations through exclusive rights to the inventions they produce.

4. Open disclosure facilities regarding information on the latest patented technology, so that the public can use it for further technological improvement and development.

\section{B. CONCLUSION}

\section{Lingkup Perlindungan Paten}

Fungsi Perlindungan: Sejauh mana invensi kita dapat dilindungi (Hak eksklusif, memberikan lisensi, menggugat, meminta ganti rugi)

Fungsi Informasi: Paten adalah monopoli yang tidak tak terbatas, merupakan kewajiban pemohon untuk mengungkapkan invensinya pada

publik sehingga dapat digunakan sebagai sumber informasi dan ide

\section{ACKNOWLEDGEMENT University Of Indonesia University Of Mitra Indonesia Telkom University University Of Mellbourne Saitama University}


Online Application In Pdam

Lampung Province," In

Prosiding International

Conference On Information

Technology And Business (Icitb), 2018, Pp. 181-187.

[2] A. S. Putra, O. M. Febriani, And B. Bachry, "Implementasi Genetic Fuzzy System Untuk Mengidentifikasi Hasil Curian Kendaraan Bermotor Di Polda Lampung," J. Sist. Inf. Dan Manaj. Basis Data, Vol. 1, No. 1, Pp. 21-30, 2018.

[3] O. M. Febriani And A. S. Putra, "Sistem Informasi Monitoring Inventori Barang Pada Balai Riset Standardisasi Industri Bandar Lampung," J. Inform., Vol. 13, No. 1, Pp. 90-98, 2014.

[4] Putra, Arie Setya. "2018 Artikel Struktur Data, Audit Dan Jaringan Komputer." (2018).

[5] Putra, A. S. (2018, July 17). Paperplain Fundamental Create Application With Borland Delphi 7.0 University Of Mitra Indonesia. Retrieved From Osf.Io/Pbrn9.

D. REFERENCE (Based ISO 690 )

[1]
A. S. Putra And O. M. Febriani, "Knowledge Management

\section{E. REFERENCE (Based APA)}

Putra, A. S., Aryanti, D. R., \& Hartati, I. (2018, November). Metode SAW (Simple Additive Weighting) sebagai Sistem Pendukung Keputusan Guru 
Berprestasi (Studi Kasus: SMK Global Surya). In Prosiding Seminar Nasional Darmajaya (Vol. 1, No. 1, pp. 85-97).

Sari, D. P., Febriani, O. M., \& Putra, A. S. (2018, November). Perancangan Sistem Informasi SDM Berprestasi pada SD Global Surya. In Prosiding Seminar Nasional Darmajaya (Vol. 1, No. 1, pp. 289-294).

Putra, A. S. (2018). Paperplain: Execution Fundamental Create Application With Borland Delphi 7.0 University Of Mitra Indonesia.

Putra, A. S., Sukri, H., \& Zuhri, K. Sistem Monitoring Realtime Jaringan Irigasi Desa (JIDES) Dengan Konsep Jaringan Sensor Nirkabel. IJEIS (Indonesian Journal of Electronics and Instrumentation Systems), 8(2), 221232.

Darmawan, A., Yuliawati, D., Marcella, O., \& Firmandala, R. (2016). Sistem Absensi dan Pelaporan Berbasis Fingerprint dan SMS Gateway. EXPLORE, 7(1).

Febriani, O. M., Wahyuni, T., \& Yusuf, S. (2017). DESIGN OF WEBSITEBASED INFORMATION SYSTEM FOR EDOCUMENT ADMINISTRASI IN THE COMMUNITY SERVICE UNIT (A Case Study at Rajabasa District). INTERNATIONAL JOURNAL OF COMPUTERS \& TECHNOLOGY, 16(7), 7010-7020.

Febriani, O. M., \& Wahyuni, T. (2017, October). PERANCANGAN SISTEM E-DOCUMENT ADMINISTRASI
LOGBOOK PENELITIAN PADA UNIT LAYANAN DI BANDAR LAMPUNG. In Prosiding Seminar Nasional Darmajaya (Vol. 1, No. 1, pp. 187-194).

Febriani, O. M., \& Permadi, A. B. (2017). Implementasi Sistem Aplikasi Data Bimbingan dan Pelanggaran Siswa pada Sekolah Menengah Atas di Lampung Tengah dengan Metode Analisis dan Desain Sistem Terdistribusi (SSAD). EXPERT, 7(1).

Febriani, O. M., \& Ambarwati, L. (2015). PERANCANGAN APLIKASI PENGOLAHAN DATA PENJUALAN UKM KELANTING KHAS TELO DESA SIDOHARJO KECAMATAN JATI AGUNG KABUPATEN LAMPUNG SELATAN. Jurnal Teknologi Informasi dan Bisnis Pengabdian Masyarakat Darmajaya, 1(1), 77-95.

Febriani, O. M. (2015). Rancang Bangun Aplikasi Ecommercemenggunakan Freewebstore pada UKM Kelanting di Desa Sidoharjo Lampung Selatan. Prosiding Sembistek 2014, 1(02), 446-458. 